\title{
Sodium Influx and Potassium Efflux Currents in Sunflower Root Cells Under High Salinity
}

\section{OPEN ACCESS}

Edited by:

Viktor Zarsky,

Charles University, Czechia

Reviewed by: Gerald Schoenknecht, Oklahoma State University, United States

Fouad Lemtiri-Chlieh, University of Connecticut, United States

*Correspondence: Vadim Demidchik dzemidchyk@bsu.by

tThese authors have contributed equally to this work

Specialty section: This article was submitted to Plant Membrane Traffic and

Transport,

a section of the journal Frontiers in Plant Science

Received: 04 October 2020 Accepted: 14 December 2020 Published: 18 January 2021

Citation: Hryvusevich P, Navaselsky I, Talkachova Y, Straltsova $D$, Keisham M, Viatoshkin A, Samokhina V, Smolich I, Sokolik A, Huang X, Yu M, Bhatla SC and Demidchik V (2021) Sodium Influx and Potassium Efflux Currents in

Sunflower Root Cells Under High Salinity.

Front. Plant Sci. 11:613936. doi: 10.3389/fp/s.2020.613936

\author{
Palina Hryvusevich ${ }^{1,2 \dagger}$, llya Navaselsky ${ }^{2 \dagger}$, Yuliya Talkachova², Darya Straltsova², \\ Monika Keisham ${ }^{3}$, Aliaksei Viatoshkin², Veranika Samokhina ${ }^{2}$, Igor Smolich², \\ Anatoliy Sokolik ${ }^{2}$, Xin Huang ${ }^{1}$, Min Yu ${ }^{1}$, Satish Chander Bhatla ${ }^{3}$ and Vadim Demidchik ${ }^{1,2 *}$ \\ ${ }^{1}$ International Research Centre for Environmental Membrane Biology, Foshan University, Foshan, China, ${ }^{2}$ Department of \\ Plant Cell Biology and Bioengineering, Biological Faculty, Belarusian State University, Minsk, Belarus, ${ }^{3}$ Laboratory of Plant \\ Physiology and Biochemistry, Department of Botany, University of Delhi, New Delhi, India
}

Helianthus annuus L. is an important oilseed crop, which exhibits moderate salt tolerance and can be cultivated in areas affected by salinity. Using patch-clamp electrophysiology, we have characterized $\mathrm{Na}^{+}$influx and $\mathrm{K}^{+}$efflux conductances in protoplasts of salt-tolerant $H$. annuus L. hybrid KBSH-53 under high salinity. This work demonstrates that the plasma membrane of sunflower root cells has a classic set of ionic conductances dominated by $\mathrm{K}^{+}$outwardly rectifying channels (KORs) and non-selective cation channels (NSCCs). KORs in sunflower show extreme $\mathrm{Na}^{+}$sensitivity at high extracellular $\left[\mathrm{Ca}^{2+}\right]$ that can potentially have a positive adaptive effect under salt stress (decreasing $\mathrm{K}^{+}$loss). $\mathrm{Na}^{+}$influx currents in sunflower roots demonstrate voltage-independent activation, lack timedependent component, and are sensitive to $\mathrm{Gd}^{3+}$. Sunflower $\mathrm{Na}^{+}$-permeable NSCCs mediate a much weaker $\mathrm{Na}^{+}$influx currents on the background of physiological levels of $\mathrm{Ca}^{2+}$ as compared to other species. This suggests that sunflower NSCCs have greater $\mathrm{Ca}^{2+}$ sensitivity. The responses of $\mathrm{Na}^{+}$influx to $\mathrm{Ca}^{2+}$ correlates well with protection of sunflower growth by external $\mathrm{Ca}^{2+}$ in seedlings treated with $\mathrm{NaCl}$. It can be, thus, hypothesized that $\mathrm{NaCl}$ tolerance in sunflower seedling roots is programmed at the ion channel level via their sensitivity to $\mathrm{Ca}^{2+}$ and $\mathrm{Na}^{+}$.

Keywords: sunflower, nonselective cation channels, potassium channels, salinity, calcium, salt stress

\section{INTRODUCTION}

Sunflower (Helianthus annuus L.) is an important crop that is widely used in the oil industry and animal feeding. Global sunflower production increased more than twice since 2000 (Pilorgé, 2020). It is the third highest oilseed produced in the world, the fourth vegetable oil and the third protein feed source among oilseed crops. Although sunflower plants exhibit medium salt 
tolerance, their production is affected by high soil salinity, which is common in arid or semi-arid areas (Karrenberg et al., 2006; Li et al., 2020). Understanding response to salinity in sunflowers and, in particular, the molecular basis of its salt tolerance mechanism is central to development of breeding and bioengineering strategies aimed to improve the salt tolerance in this species.

The major toxic ions in salinized soils are $\mathrm{Na}^{+}$and $\mathrm{Cl}^{-}$, although $\mathrm{SO}_{4}{ }^{2-}, \mathrm{HCO}_{3}^{-}, \mathrm{Mg}^{2+}$, and other chemical species also contribute to the harmful salinity effects among higher plants. Slower growth is observed in plant species in the presence of external $40-50 \mathrm{mM} \mathrm{NaCl}$, while the treatment by $100-150 \mathrm{mM}$ $\mathrm{NaCl}$ is usually lethal (Flowers et al., 1986; Munns and Tester, 2008). Some species and cultivars tolerate up to $200-400 \mathrm{mM}$ $\mathrm{NaCl}$, and they are considered salt-tolerant or halophytic species (Shabala, 2013; Flowers and Colmer, 2015). Agriculturally important $H$. annuus $\mathrm{L}$. cultivars survive at $100-150 \mathrm{mM}$ $\mathrm{NaCl}$ while some wild sunflower species, such as halophytic Helianthus paradoxus, can withstand much higher levels of $\mathrm{NaCl}$ (Karrenberg et al., 2006; Grieve et al., 2012).

The physiological response to salinity is a complex phenomenon that normally includes rapid $\mathrm{Na}^{+}$influx in root cells, triggering early signaling and defense reactions and longerterm $\mathrm{NaCl}$-induced processes which develop within 1-2 weeks, and subsequently target photosynthetic tissues as the plants grow (Munns and Tester, 2008; Flowers et al., 2014; Negrão and Schmöckel, 2017). High levels of $\mathrm{Na}^{+}$and $\mathrm{Cl}^{-}$do not have specific cellular targets. Therefore, $\mathrm{NaCl}$ toxicity is related to a long-term and non-specific disturbance of cellular osmotic, ionic, electric, redox and metabolic balance, inhibiting photosynthesis, respiration, growth, development and reproduction (Shabala, 2013; Demidchik et al., 2014, 2018; Negrão and Schmöckel, 2017; Isayenkov and Maathuis, 2019). It is generally accepted that $\mathrm{Na}^{+}$is more toxic than $\mathrm{Cl}^{-}$for most plant species (Shabala, 2013; Flowers and Colmer, 2015), although the detrimental effect of $\mathrm{Cl}^{-}$should not be underestimated (White and Broadley, 2003; Li et al., 2020). The key mechanisms of toxic $\mathrm{Na}^{+}$influx into the root cells is its entry through the plasma membrane-associated non-selective cation channels (NSCCs; Demidchik and Tester, 2002; Shabala et al., 2006; Demidchik and Maathuis, 2007). However, the existence of other pathways, such as HKT1-type transporters and $\mathrm{K}^{+}$-selective channels, has also been hypothesized (Xue et al., 2011; Flowers et al., 2014; Assaha et al., 2017). Influx of $\mathrm{Na}^{+}$through NSCCs results in plasma membrane depolarization, which is probably the earliest physiological response to $\mathrm{NaCl}$, leading to the activation of $\mathrm{Ca}^{2+}$ influx, $\mathrm{K}^{+}$, and anion efflux and water release for osmotic balance (Demidchik and Tester, 2002; Shabala et al., 2006). $\mathrm{Na}^{+}$influx-induced depolarization triggers the generation of reactive oxygen species (ROS) catalyzed by nicotinamide adenine dinucleotide phosphate (NADPH) oxidases and other redox systems which additionally stimulate $\mathrm{Ca}^{2+}$ influx and loss of $\mathrm{K}^{+}$(as well as the loss of other electrolytes), leading to a long-term ionic and redox disequilibrium, which is considered to be the prime reason for $\mathrm{NaCl}$ toxicity among most plants (Demidchik et al., 2014; Demidchik and Shabala, 2018).
$\mathrm{Na}^{+}$influx through NSCCs can be inhibited by increased external $\left[\mathrm{Ca}^{2+}\right]$ (Demidchik and Tester, 2002). This phenomenon is widely used in agriculture to ameliorate $\mathrm{NaCl}$ toxicity (Bressan et al., 1998). We have previously found that high external $\mathrm{Ca}^{2+}$ levels inhibit both $\mathrm{Na}^{+}$entry and $\mathrm{K}^{+}$efflux channels, thereby blocking both $\mathrm{Na}^{+}$toxic influx and loss of $\mathrm{K}^{+}$(Shabala et al., 2006). In the recent past, blockade of $\mathrm{Na}^{+}$influx by external $\mathrm{Ca}^{2+}$ has only been investigated in Arabidopsis thaliana (Demidchik and Tester, 2002; Shabala et al., 2006). Therefore, it is still unclear whether other plants share this mechanism.

In the present investigations, using patch-clamp electrophysiology, we have characterized the NSCC-like $\mathrm{Na}^{+}$ conductance and determined its $\mathrm{Ca}^{2+}$ sensitivity in root protoplasts of $H$. annuus L. seedlings (hybrid $\mathrm{KBSH}-53$ ), which is widely cultivated in arid regions of India. To our knowledge, this is the first electrophysiological study of any ion currents in sunflower as well as properties of $\mathrm{Na}^{+}$influx and $\mathrm{K}^{+}$efflux conductances in this species.

\section{MATERIALS AND METHODS}

\section{Plant Material}

Helianthus annuus L. (cv Karnataka Bangalore Sunflower HyBrid 53, KBSH-53) was from the collection of Department of Botany, University of Delhi (India). For patch-clamp experiments, sunflower seeds were surface-sterilized with $20 \%(\mathrm{w} / \mathrm{v})$ Domestos bleach, germinated on wetted filter paper (2 days), and then cultivated vertically in filter paper rolls immersed in solution containing 10\% standard Murashige and Skoog nutrient medium (MS; Duchefa \#M0221, original composition; Murashige and Skoog, 1962), pH 6.0 was adjusted by KOH. Six-to-twelve day-old seedlings were used for patch-clamp experiments. Root protoplasts were initially isolated using techniques developed by Demidchik and Tester (2002). Three-cm-long root tips from 10 to 15 seedlings were excised, chopped into small pieces (1-2 $\mathrm{mm})$ and placed in the solution with cellulytic enzymes for protoplasts isolation comprising 1.5\% (w/v) Cellulase Onozuka RS (Yakult Honsha, Tokyo, Japan), 1\% (w/v) cellulysin (CalBiochem, Nottingham, United Kingdom), 0.1\% (w/v) pectolyase Y-23 (Yakult Honsha, Tokyo, Japan), 0.1\% (w/v) bovine serum albumin (Sigma), $10 \mathrm{mM} \mathrm{KCl}, 10 \mathrm{mM} \mathrm{CaCl}$, $2 \mathrm{mM} \mathrm{MgCl}_{2}, 2 \mathrm{mM}$ MES, pH 6.0 with Tris, and $600 \mathrm{mOsm} \mathrm{kg}{ }^{-1}$ adjusted with D-sorbitol. This protocol was adjusted as indicated in "Results" section. After gentle shaking ( $45 \mathrm{rpm}$ ) in the enzyme solution for $30-50 \mathrm{~min}$ at $28^{\circ} \mathrm{C}$, protoplasts were filtered $(30-\mu \mathrm{m}$ pore mesh) and rinsed with holding solution (HS: $5 \mathrm{mM} \mathrm{KCl}$, $2 \mathrm{mM} \mathrm{CaCl}_{2}, 1 \mathrm{mM} \mathrm{MgCl}, 10 \mathrm{mM}$ sucrose, $10 \mathrm{mM}$ glucose, $2 \mathrm{mM}$ MES, pH 6.0 with Tris, and $600 \mathrm{mOsm} \mathrm{kg}^{-1}$ with D-sorbitol). Protoplasts were collected by 5 -min centrifugation at $200 \mathrm{~g}$ and stored on ice in holding solution.

The hydroponic cultivation system was used for sunflower root growth measurements. Germinated seeds (germination: 2 days on wetted filter paper) were cultivated during 7 days in vertical polycarbonate sheets. Each root was directed to a separate channel of polycarbonate sheets in order to prevent root entanglement (Green House Polycarbonate Sheets; 
Greenhouse Megastore, United States). Polycarbonate sheets were mounted vertically in large square glass vessel and dipped into the medium (volume: $2 \mathrm{~L}$ ), which was stirred with a stream of air (air compressor Barbus Aquael OXYPRO; China). The medium contained 5\% original Murashige and Skoog nutrient composition (MS; Duchefa \#M0221; Murashige and Skoog, 1962), pH 6.0 (adjusted by $\mathrm{KOH})$. Treatments $\left(\mathrm{CaCl}_{2}\right.$, $\mathrm{NaCl}$, etc.) were added to this medium as required. All growth solutions were replaced every day (for freshness). Root length (main root) was measured after 7 days of treatment.

\section{Patch-Clamp Measurements}

Conventional patch-clamp and protoplast isolation techniques were used (Demidchik and Tester, 2002; Demidchik et al., 2010). The standard bathing solution contained (in $\mathrm{mM}$ ): $0.3 \mathrm{KCl}, 2$ Tris, adjusted to $\mathrm{pH} 6.0$ with $1 \mathrm{MES}$, and $600 \mathrm{mOsm} \mathrm{kg}^{-1}$, with D-sorbitol. Other salines are indicated in figure legends. A freshly prepared mixture of this solution was applied in whole-cell outside-out patches. The pipette solution (PS) contained the following composition (mM): 70 KGluconate, $10 \mathrm{KCl}, 1 \mathrm{mM}$ 1,2-bis(o-aminophenoxy)ethane-N,N,N0,N0-tetraacetic acid (BAPTA) and $0.475 \mathrm{mM} \mathrm{CaCl}_{2}\left(10 \mathrm{nM}\right.$ free $\left.\mathrm{Ca}^{2+}\right), \mathrm{pH} 7.2$ with 2 Tris, and 1 MES. To examine the sensitivity of wholecell outward current to cation channel blockers (TEA ${ }^{+}$and
$\mathrm{Gd}^{3+}$ ), $10 \mathrm{mM}$ TEACl or $100 \mu \mathrm{M} \mathrm{GdCl}_{3}$ were added to the bathing solution. The size of protoplasts was measured using Nikon NIS-Elements software and used to calculate the mA/ $\mathrm{m}^{2}$ current densities. Typical transmembrane currents are from the same cell (including $\mathrm{Gd}^{3+}$ blockade test). Liquid junction potentials were calculated by JPCalc, which is included in Axon Clampex 10.6 software (Molecular Devices, United States) and corrected. The voltage was held at $-90 \mathrm{mV}$, then square $7.6 \mathrm{~s}$-long or $1.5 \mathrm{~s}$-long depolarizing or hyperpolarizing voltage pulses were applied. Currents were measured using PC-ONE Patch/ Whole Cell Clamp (CORNERSTONE Series) amplifier (Dagan Corporation, United States) controlled by Digidata 1,320/Clampex 10.6 (Molecular Devices, United States). Current-voltage (I-V) and other curves were plotted and analyzed using SigmaPlot 10.0 (Systat Software Inc., United States).

\section{RESULTS}

\section{Effect of $\mathrm{Ca}^{2+}$ on Sunflower Seedling Growth in High Salinity Conditions}

Root growth tests were carried out using seedlings of $H$. annuus L. KBSH-53 in vertical hydroponic chambers in controlled environment (Figure 1). The effect of 80 and
A

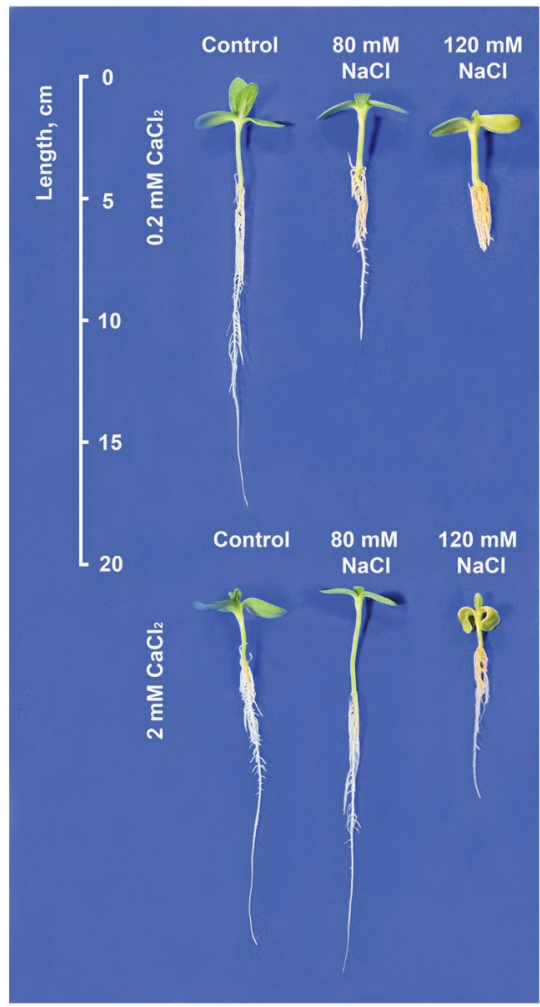

B

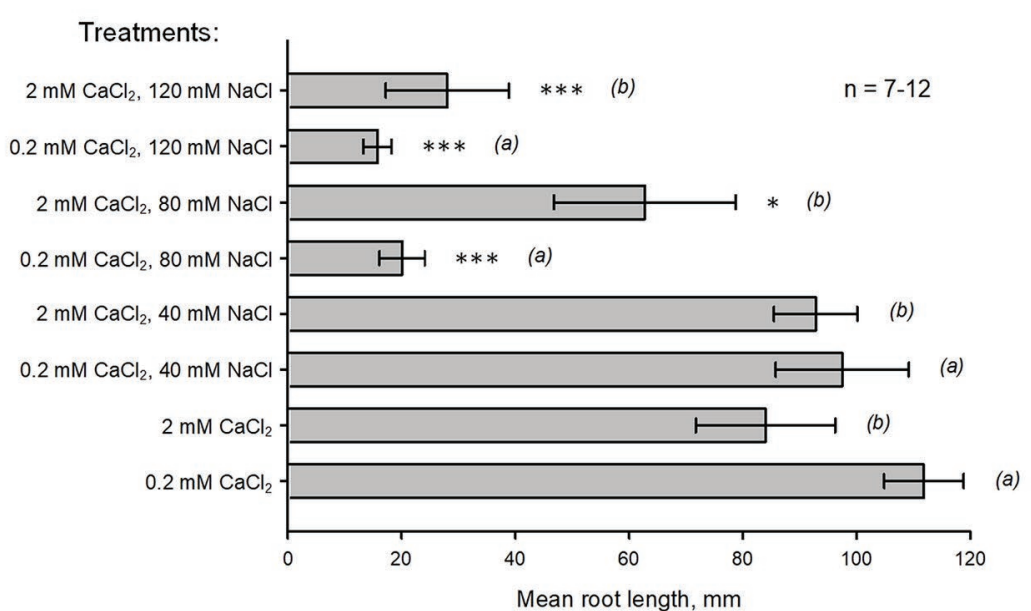

FIGURE 1 | Effect of external $\mathrm{Ca}^{2+}$ on the inhibition of $\mathrm{H}$. annuus L. root growth induced by $\mathrm{NaCl}$. (A) Typical sunflower seedlings cultivated in hydroponics during 7 days (after 2-day germination) on the background of 0.2 or $2 \mathrm{mM} \mathrm{CaCl}_{2}$ (upper and lower panels, respectively). "Control": plants grown in control conditions (5\% MS; pH 6.0). "80 mM NaCl" and "120 mM NaCl": plants grown in the presence of 80 or $120 \mathrm{mM} \mathrm{NaCl}$, respectively. (B) Mean \pm SE (n= 7-12) root length values measured in different conditions (as indicated in the figure). (a) and (b) are groups for comparison (ANOVA test); ${ }^{p} p<0.01 ;{ }^{* * * *} p<0.0001$. 
$120 \mathrm{mM} \mathrm{NaCl}$ on the length of main root was examined (preliminary tests showed that $40 \mathrm{mM} \mathrm{NaCl}$ did not modify plant growth). Measurements were carried out against two levels of $\mathrm{Ca}^{2+}(0.2$ and $2 \mathrm{mM})$ in the cultivation solution containing 5\% MS (original composition). Growth in $\mathrm{NaCl}-$ free solutions (control conditions) containing $2 \mathrm{mM} \mathrm{CaCl}$ was approximately $25 \%$ slower than growth on the background of $0.2 \mathrm{mM} \mathrm{CaCl}_{2}$ ( $p=0.007$; seven independent trials; each trial included 9-10 plants). Addition of $80 \mathrm{mM} \mathrm{NaCl}$ along with $0.2 \mathrm{mM} \mathrm{CaCl}_{2}$ resulted in approximately 5 -fold decrease of root length $(p<0.001 ; 12$ independent trials; each trial included 9-10 plants). At the same time, $120 \mathrm{mM} \mathrm{NaCl}$ induced 6.5-fold delay in growth. Increase of external $\mathrm{Ca}^{2+}$ level from 0.2 to $2 \mathrm{mM}$ significantly improved plant growth in the presence of $\mathrm{NaCl}$. In this case, application of $80 \mathrm{NaCl}$ did not induce statistically significant decrease of root length $(p=0.235 ; 11$ independent trials; each trial included $8-10$ plants) while the effect of $120 \mathrm{mM} \mathrm{NaCl}$ was twice smaller ( $p=0.008$; eight independent trials; each trial contained eight plants; comparison with $0.2 \mathrm{mM} \mathrm{CaCl}_{2}$ ). Overall, these data show that $\mathrm{Ca}^{2+}$ (the physiological range) has a strong ameliorative effect on the growth of $H$. annuus L. KBSH-53 roots in salinized conditions.

\section{Protoplast Isolation and Obtaining Gigaohmic Resistance Patches}

No reports have been published about transmembrane currents of $H$. annuus $\mathrm{L}$. or protocols for protoplast isolation for patchclamp tests in this species. To our knowledge, several attempts have been made to isolate sunflower protoplasts suitable for patch-clamp studies but none of them were successful for implementation in routine electrophysiological practice. In most cases, protoplast isolation from sunflower required overnight treatment by enzymes and did not yield viable protoplasts from any tissues apart from hypocotyl (Lenee and Chupeau, 1986; Kativat et al., 2012). We have developed protocols for $H$. annuus $\mathrm{L}$. root patch-clamp analyses that were based on previous protocols elaborated for A. thaliana and Triticum aestivum (Demidchik and Tester, 2002; Demidchik et al., 2010; Straltsova et al., 2015; Sosan et al., 2016; Makavitskaya et al., 2018). Ten osmolality levels were examined (300-750 mOsm kg-1; $50 \mathrm{mOsm} \mathrm{kg^{-1 }}$ step) in 10 replicates. Round shaped viable protoplasts were observed only at 600 and $650 \mathrm{mOsm} \mathrm{\textrm {kg } ^ { - 1 }}$ but the density of viable protoplasts was approximately six times higher at $600 \mathrm{mOsm} \mathrm{kg}{ }^{-1}$ comparing to $650 \mathrm{mOsm} \mathrm{kg} \mathrm{kg}^{-1}$ (up to $55 \pm 4$ viable protoplasts per $1 \mathrm{ml}$ of the enzyme solution; mean $\pm \mathrm{SE} ; n=10$ ). Experimental work on protoplasts reported here was carried out using the osmolality level of $600 \mathrm{mOsm} \mathrm{kg}^{-1}$.

We have previously developed techniques and voltage-clamp protocols for the patch-clamp analysis of inwardly- and outwardlydirected conductances in higher plants, including $\mathrm{Na}^{+}$-conducting NSCCs (Demidchik and Tester, 2002; Demidchik et al., 2010). The probability rate of observing "gigaohmic" contact required for patch-clamp measurements in sunflower protoplasts was low (2,750 protoplasts were patch-clamped; "gigaohmic" contact formed in 409 protoplasts). Approximately one-third of these protoplasts survived after addition of high $\mathrm{NaCl}$ concentration and maintained gigaohmic pipette resistance (139 protoplasts). A number of methods for improving patch stability were applied (different levels of external $\mathrm{Ca}^{2+}, \mathrm{H}^{+}$, use of $\mathrm{Na}^{+}$instead $\mathrm{K}^{+}$ in the patch-clamp pipette, additional pipette polishing, hydrophobic coating, etc.) but none of these significantly improved the "gigaseal."

\section{Currents of Sunflower Root Protoplasts in Control Conditions and in Presence of $\mathrm{NaCl}$}

Protoplasts were patch-clamped in the sealing solution containing $20 \mathrm{mM} \mathrm{CaCl}_{2}$ and $0.3 \mathrm{mM} \mathrm{KCl}(\mathrm{pH}$ 6.0) using pipettes filled with the solution comprising of $70 \mathrm{mM}$ KGluconate and $10 \mathrm{mM} \mathrm{KCl}\left(\mathrm{pH} 7.2,100 \mathrm{nM} \mathrm{Ca}^{2+}\right)$. High external $\mathrm{Ca}^{2+}$ allowed gigaseal formation (Demidchik and Tester, 2002), while high intracellular (pipette) $\mathrm{K}^{+}$"mimicked" cellular $\mathrm{K}^{+}$level (Demidchik, 2014). Potassium gluconate $(70 \mathrm{mM})$ in the pipette solution was used instead of $\mathrm{KCl}$ to avoid $\mathrm{Cl}^{-}$efflux currents, which can overlap with $\mathrm{Na}^{+}$influx conductance. Gluconate is a poorly permeable organic anion that minimizes anion efflux currents in patch-clamped root protoplasts (Makavitskaya et al., 2018). In these conditions, a moderate negative inwardly directed current was measured (Figure 2A). This current was voltage-independent and sensitive to $100 \mu \mathrm{M} \mathrm{Gd}^{3+}(77.3 \pm 4.5 \%$ decrease of the amplitude; \pm SE; $n=5$; data not shown). It showed very rapid ("instantaneous") activation kinetics. When external $\mathrm{CaCl}_{2}$ was decreased from 20 to $0.2 \mathrm{mM}$, this current decreased by five times, demonstrating that it was mediated by $\mathrm{Ca}^{2+}$ influx (Figures 2-4, 5; $p<0.001 ; n=5$ ). These $\mathrm{Ca}^{2+}$ currents were similar to NSCC-mediated $\mathrm{Ca}^{2+}$ currents previously reported in A. thaliana root protoplasts (Demidchik et al., 2002). It should be noted that in Arabidopsis, NSCCs mediating these currents were $\mathrm{Na}^{+}$-permeable (Demidchik et al., 2002; Demidchik and Tester, 2002). Addition of $\mathrm{NaCl}$ to patchclamped protoplasts in the presence of $20 \mathrm{mM}$ extracellular $\mathrm{Ca}^{2+}$ did not induce inwardly directed current (as expected for $\mathrm{Na}^{+}$influx NSCCs). The reversal potential was $-91 \pm 4 \mathrm{mV}$ $(20 \mathrm{mM} \mathrm{CaCl} ; \pm \mathrm{SE} ; n=11)$ and it was not modified by $\mathrm{NaCl}$ addition (Figure 2).

The outward current measured in the presence of $20 \mathrm{mM}$ external $\mathrm{CaCl}_{2}$ was significantly blocked by the addition of $\mathrm{NaCl}$ to the bathing solution (Figure 2). The outwardly directed conductance dropped three times when $80 \mathrm{mM} \mathrm{NaCl}$ was added (Figure 5). In the conditions used in the work, the outward current could be mediated by $\mathrm{K}^{+}$efflux through KORs or by $\mathrm{Cl}^{-}$influx via anion channels (Demidcik et al., 2002, 2014; de Angeli et al., 2007; Demidchik, 2012; Hedrich, 2012). However, only $\mathrm{K}^{+}$currents can be blocked by $\mathrm{Na}^{+}$because the anion channels are insensitive to this and other alkali metals (Barbier-Brygoo et al., 2000). Moreover, the addition of $\mathrm{K}^{+}$channel blocker $\mathrm{TEA}^{+}(30 \mathrm{mM}$ TEACl) inside the patchclamp pipette instead of $80 \mathrm{mM} \mathrm{K} \mathrm{K}^{+}(70 \mathrm{mM}$ KGluc and $10 \mathrm{mM}$ $\mathrm{KCl})$ decreased the outward current by $8-9$ times $(p<0.001$; $n=5$; data not shown) demonstrating that this current was mediated by KORs. 
A

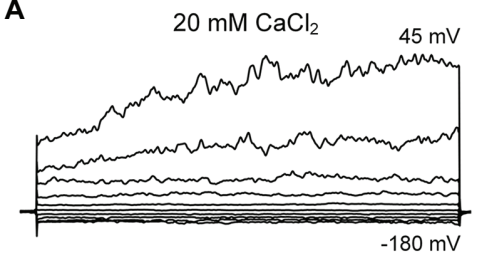

$20 \mathrm{mM} \mathrm{CaCl}_{2}, 40 \mathrm{mM} \mathrm{NaCl}$

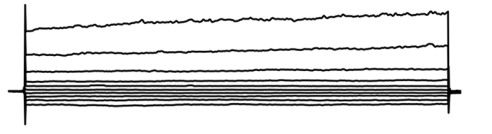

$20 \mathrm{mM} \mathrm{CaCl}_{2}, 80 \mathrm{mM} \mathrm{NaCl}$

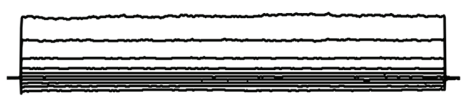

$100 \mathrm{~mA} \mathrm{~m}^{-2}$

$2 \mathrm{~s}$
B
- $20 \mathrm{mM} \mathrm{CaCl}$
口 $20 \mathrm{mM} \mathrm{CaCl}_{2}, 40 \mathrm{mM} \mathrm{NaCl}$
$\triangle 20 \mathrm{mM} \mathrm{CaCl}_{2}, 80 \mathrm{mM} \mathrm{NaCl}$

$n=7-11$

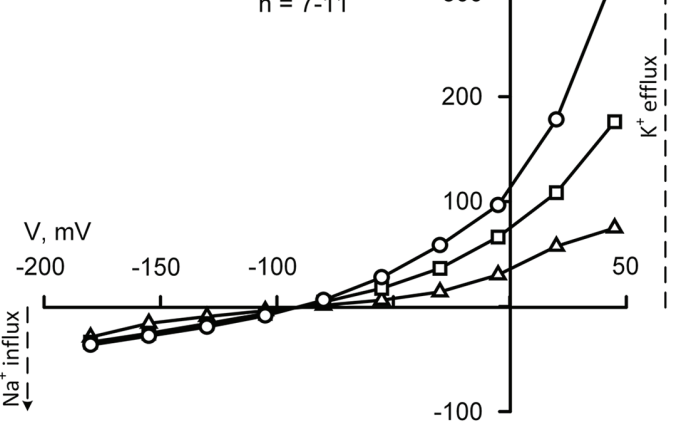

FIGURE 2 | Typical plasma membrane currents (A) and mean current-voltage curves (B) in Helianthus annuus L. root protoplasts recorded in the presence of $20 \mathrm{mM} \mathrm{CaCl}_{2}$ in the bathing solution at different levels of external $\mathrm{NaCl}(40$ and $80 \mathrm{mM})$. Current-voltage curves were plotted by mean values $(n=7-11$; errors are not shown in the figure). Statistically significant $(p<0.01$ ) difference between mean currents was found at voltage values exceeding $-30 \mathrm{mV}$ (ANOVA test). The standard bathing solution contained (in $\mathrm{mM}$ ): $0.3 \mathrm{KCl}, 2$ Tris, adjusted to $\mathrm{pH} 6.0$ with $1 \mathrm{MES}$, and $600 \mathrm{mOsM}$, with D-sorbitol. The pipette solution contained $70 \mathrm{mM} \mathrm{K}$ gluconate, $10 \mathrm{mM} \mathrm{KCl} ; 100 \mathrm{nM} \mathrm{Ca}{ }^{2+}$ was adjusted with $1 \mathrm{mM}$ BAPTA and $0.475 \mathrm{mM} \mathrm{CaCl}$, pH 7.2 with $2 \mathrm{mM}$ Tris, 1 mM MES.

A

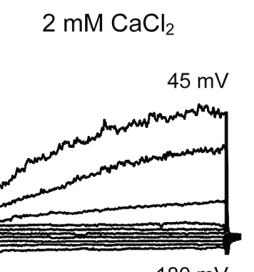

$-180 \mathrm{mV}$

$2 \mathrm{mM} \mathrm{CaCl}_{2}$, $80 \mathrm{mM} \mathrm{NaCl}$

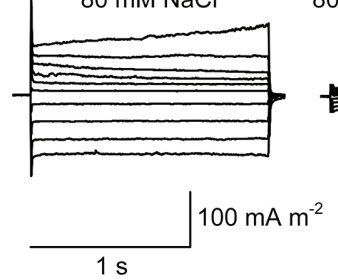

$2 \mathrm{mM} \mathrm{CaCl}_{2}$, $40 \mathrm{mM} \mathrm{NaCl}$

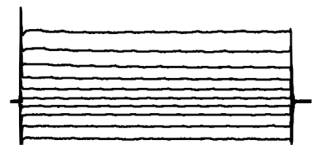

$2 \mathrm{mM} \mathrm{CaCl}_{2}$, $80 \mathrm{mM} \mathrm{NaCl}, 100 \mu \mathrm{M} \mathrm{GdCl}_{3}$

B

$$
\begin{aligned}
& \text { ○ } 2 \mathrm{mM} \mathrm{CaCl}_{2} \\
& \text { - } 2 \mathrm{mM} \mathrm{CaCl}_{2}, 40 \mathrm{mM} \mathrm{NaCl} \\
& \triangle 2 \mathrm{mM} \mathrm{CaCl}_{2}, 80 \mathrm{mM} \mathrm{NaCl} \\
& \diamond 2 \mathrm{mM} \mathrm{CaCl}_{2}, 80 \mathrm{mM} \mathrm{NaCl}, \\
& 100 \mathrm{MM} \mathrm{GdCl}_{3}
\end{aligned}
$$

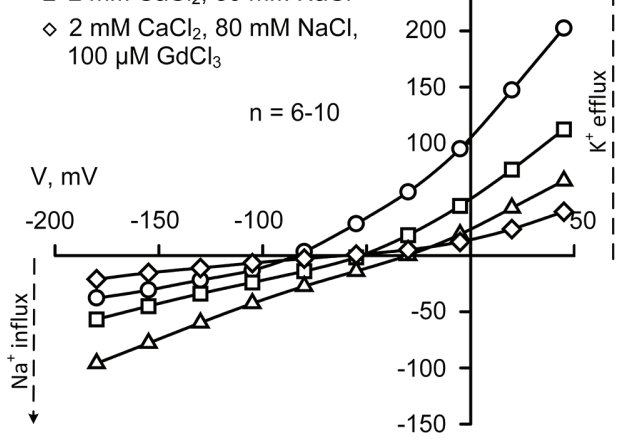

FIGURE 3 | Typical plasma membrane currents (A) and mean current-voltage curves (B) in H. annuus L. root protoplasts recorded in the presence of 2 mM CaCl 2 in the bathing solution at different levels of external $\mathrm{NaCl}(40$ and $80 \mathrm{mM})$. Current-voltage curves were plotted by mean values $(n=6-10$; errors are not shown in the figure). Statistically significant ( $p<0.01$; ANOVA test) difference between " $2 \mathrm{mM} \mathrm{CaCl}_{2}$ " (circles) and " $40 \mathrm{mM} \mathrm{NaCl"} \mathrm{(squares)} \mathrm{was} \mathrm{found} \mathrm{at} \mathrm{all} \mathrm{voltage} \mathrm{values}$ apart from $-105 \mathrm{mV}$. The difference between "2 mM CaCl." (circles) and "80 mM NaCl" (triangles) was statistically significant at all voltage values $(p<0.01$; ANOVA test). The standard bathing solution contained (in $\mathrm{mM}$ ): $0.3 \mathrm{KCl}, 2$ Tris, adjusted to $\mathrm{pH} 6.0$ with $1 \mathrm{MES}$, and $600 \mathrm{mOsM}$, with D-sorbitol. The pipette solution contained $70 \mathrm{mM} \mathrm{K}$ gluconate, $10 \mathrm{mM} \mathrm{KCl} ; 00 \mathrm{nM} \mathrm{Ca}^{2+}$ was adjusted with $1 \mathrm{mM} \mathrm{BAPTA}$ and $0.475 \mathrm{mM} \mathrm{CaCl}_{2}, \mathrm{pH}_{7.2}$ with 2 mM Tris, 1 mM MES. $100 \mu$ M GdCl ${ }_{3}$ was added to the bathing solution on the background of $2 \mathrm{mM} \mathrm{CaCl}_{2}$ and $80 \mathrm{mM} \mathrm{NaCl}$ for 5 min before recording current-voltage curves.

The time-dependent component of the outward $\mathrm{K}^{+}$current was inhibited after the addition of $\mathrm{NaCl}$ to the bathing solution while instantaneous current remained very similar (Figure 2). It can be thus hypothesized that the residual outward current was mediated by anion channel-catalyzed $\mathrm{Cl}^{-}$influx or $\mathrm{K}^{+}$ efflux via NSCCs (previously described in Shabala et al., 2006). The maximal reduction of the outward current was 4.3 , as measured in the presence of $80 \mathrm{NaCl}$ at 7.6 depolarizing pulses 
A

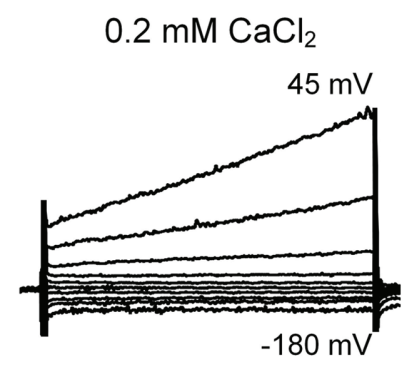

$0.2 \mathrm{mM} \mathrm{CaCl}_{2}$,

$40 \mathrm{mM} \mathrm{NaCl}$

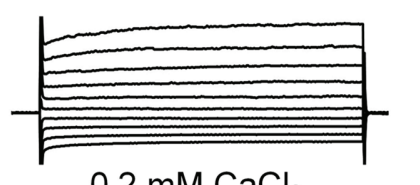

$0.2 \mathrm{mM} \mathrm{CaCl}_{2}$,

$80 \mathrm{mM} \mathrm{NaCl}$

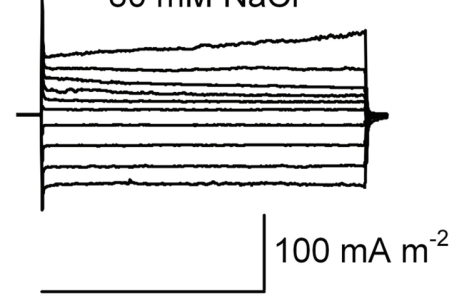

$1 \mathrm{~s}$
B

I, $\mathrm{mA} \mathrm{m}^{-2}$

○ $0.2 \mathrm{mM} \mathrm{CaCl}_{2}$

ㅁ $0.2 \mathrm{mM} \mathrm{CaCl}_{2}, 40 \mathrm{mM} \mathrm{NaCl}$

$\triangle 0.2 \mathrm{mM} \mathrm{CaCl}_{2}, 80 \mathrm{mM} \mathrm{NaCl}$

$n=5-6$

$200-100-\frac{i}{i}$

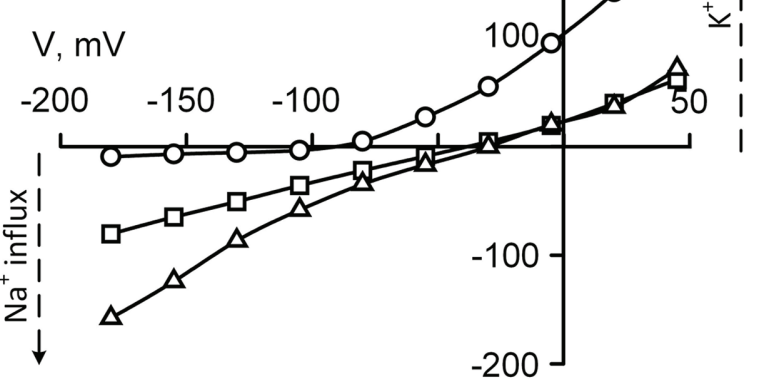

FIGURE 4 | Typical plasma membrane currents (A) and mean current-voltage curves (B) in H. annuus L. root protoplasts recorded in the presence of $0.2 \mathrm{mM}$ $\mathrm{CaCl}_{2}$ in the bathing solution at different levels of external $\mathrm{NaCl}(40$ and $80 \mathrm{mM})$. Current-voltage curves were plotted by mean values $(n=5-6$; errors are not shown in the figure). The difference between " $0.2 \mathrm{mM} \mathrm{CaCl}_{2}$ " (circles) and " $40 \mathrm{mM} \mathrm{NaCl}$ " (squares) as well as between " $0.2 \mathrm{mM} \mathrm{CaCl}_{2}$ " (circles) and " $80 \mathrm{mM} \mathrm{NaCl"}$ (triangles) was statistically significant at all voltage values $(p<0.01$; ANOVA test). Statistically significant $(p<0.01$; ANOVA test) difference between " $40 \mathrm{mM}$ NaCl" (squares) and " $80 \mathrm{mM} \mathrm{NaCl}$ " (triangles) was found at a voltage of more negative than $-80 \mathrm{mV}$. The standard bathing solution contained (in mM): $0.3 \mathrm{KCl}, 2$ Tris, adjusted to $\mathrm{pH} 6.0$ with $1 \mathrm{MES}$, and $600 \mathrm{mOsM}$, with D-sorbitol. The pipette solution contained $70 \mathrm{mM} \mathrm{K}$ gluconate, $10 \mathrm{mM} \mathrm{KCl;} 100 \mathrm{nM} \mathrm{Ca}{ }^{2+}$ was adjusted with $1 \mathrm{mM} \mathrm{BAPTA}$ and $0.475 \mathrm{mM} \mathrm{CaCl}_{2}$, pH 7.2 with $2 \mathrm{mM}$ Tris, 1 mM MES.

(Figure 2). This reduction was 3.2 times as calculated for 1.5-s-long segments of depolarising pulses (directly comparable with pulses used in Figures 3, 4). These results demonstrate a high sensitivity of $\mathrm{KOR}$ to $\mathrm{Na}^{+}$and suggest a relatively low sensitivity of KOR to external $\mathrm{Ca}^{2+}$ in salt-tolerant sunflower.

\section{Sodium Influx Currents in Sunflower Root Protoplasts Under Low External $\mathrm{Ca}^{2+}$}

Calcium ions are blockers of plant $\mathrm{Na}^{+}$-permeable NSCCs (Demidchik and Tester, 2002; Shabala et al., 2006). This may be the reason for no detection of $\mathrm{Na}^{+}$influx conductance in the presence of $20 \mathrm{mM} \mathrm{CaCl}$ (Figure 2). However, the decrease of external $\mathrm{Ca}^{2+}$ from 20 to $2 \mathrm{mM}$ (typical soil solution level of $\mathrm{Ca}^{2+}$; White and Broadley, 2003; Marschner, 2011) resulted in the increase in the inward $\mathrm{Na}^{+}$current, which correlated with a shift of reversal potential to more positive values (from $-86.6 \pm 3.2 \mathrm{mV}$ in control to $-49.8 \pm 2.5 \mathrm{mV}$ at $40 \mathrm{mM} \mathrm{NaCl}$ and $-30.1 \pm 1.8 \mathrm{mV}$ at $80 \mathrm{mM} \mathrm{NaCl} \pm \pm$ SE; $n=6-11$ ), consistent with currents being dominated by the movement of $\mathrm{Na}^{+}$(Figure 3 ). This can be interpreted as weakening the $\mathrm{Ca}^{2+}$-induced blockade of the NSCCs. Sodium influx current showed an "instantaneous" kinetics and was voltage-independent.

The shift of the reversal potential in response to $\mathrm{NaCl}$ to more positive values decreased the KOR-mediated outwardlydirected currents (as the activation curve moved positive). Moreover, the decrease of the external $\mathrm{CaCl}_{2}$ destabilized patches and caused a breakdown at depolarization that did not allow depolarizing pulses longer than $1.5 \mathrm{~s}$ (note: $7.6 \mathrm{~s}$-long pulses were applied at $20 \mathrm{mM} \mathrm{CaCl}_{2}$ to record full activation of KORs). In this regard, the measurements were limited to shorter segments of the outwardly-directed $\mathrm{K}^{+}$currents (Figure 3; see also calculation of conductance change in Figure 5), and it was not possible to fully compare the data with those shown in Figure 2. The obtained data demonstrated that an addition of $\mathrm{NaCl}$ (both 40 and $80 \mathrm{mM}$ ), in the presence of $2 \mathrm{mM} \mathrm{CaCl}_{2}$, inhibited the outwardly-directed currents slightly weaker than in the presence of $20 \mathrm{mM} \mathrm{CaCl}$ (Figures 3, 5). The time-dependent component of the current was almost fully inhibited. 


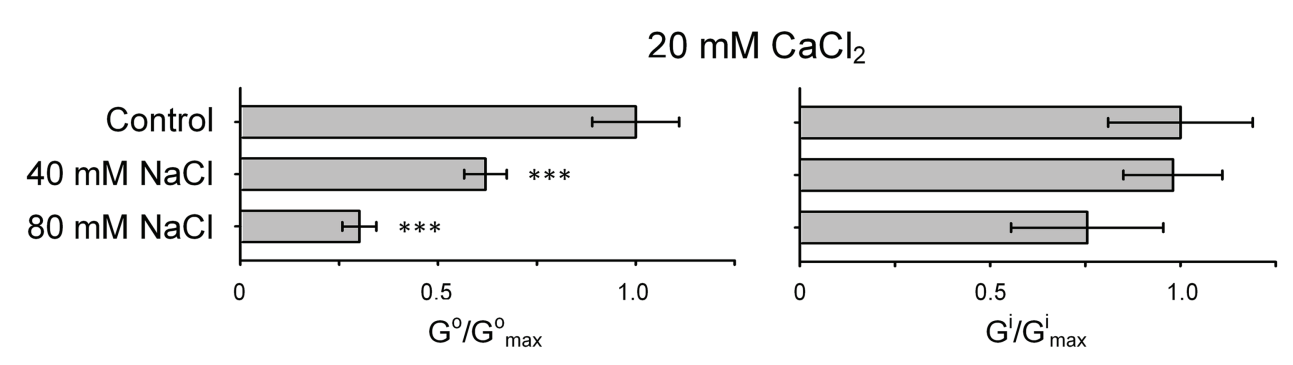

$2 \mathrm{mM} \mathrm{CaCl}_{2}$
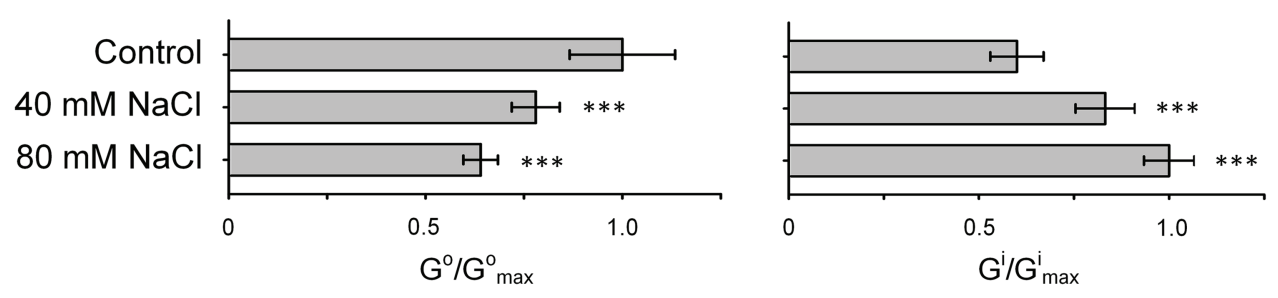

$0.2 \mathrm{mM} \mathrm{CaCl}_{2}$
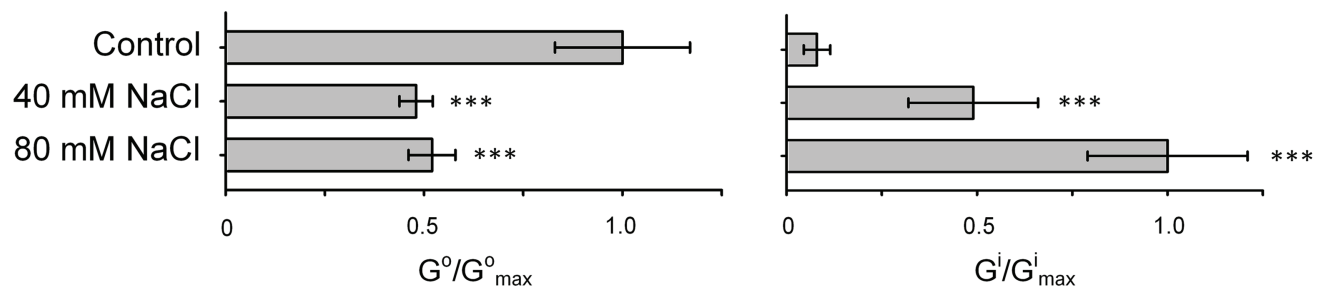

FIGURE 5 | Changes in outwardly $\left(\mathrm{G}^{\circ}\right)$ and inwardly (Gi) directed conductance in $\mathrm{H}$. annuus L. root protoplasts induced by addition of 40 or 80 mM NaCl to the external solution. The outwardly directed and inwardly directed conductance values were calculated using currents induced by voltage segment within the reversal potential to $50 \mathrm{mV}$ and - $180 \mathrm{mV}$, respectively (based on IV curves shown in Figures 2-4). $\mathrm{G}_{\max }$ is the maximal value of conductance measured calculated in an individual experiment (set of IV curves). Experimental conditions and ionic species in external and pipette solutions are same as in Figures 2-4. Data are mean \pm SE ( $n=5-11 ;{ }^{* * *} p<0.0001$; ANOVA test; comparison to control; no significant difference where unmarked).

The addition of $100 \mu \mathrm{M} \mathrm{Gd}{ }^{3+}$, which is a non-specific blocker of NSCCs and other plant cation channels (Demidchik and Maathuis, 2007) to the bathing solution containing $2 \mathrm{mM}$ $\mathrm{CaCl}_{2}$ and $80 \mathrm{mM} \mathrm{NaCl}$, caused a very strong inhibition of both inward and outward currents (5-6-fold decrease of currents; Figure 3). This indicates that both currents were mediated by cation channels (not by anion channels).

Lowering the external $\mathrm{CaCl}_{2}$ from 2 to $0.2 \mathrm{mM}$ in the presence of 40 or $80 \mathrm{mM} \mathrm{NaCl}$ resulted in further increase in inwardly-directed voltage-independent $\mathrm{Na}^{+}$current (Figure 4). The reversal potential values measured after the addition of 40 and $80 \mathrm{mM} \mathrm{NaCl}$ were $-37.4 \pm 2.9 \mathrm{mV}$ and $-26.5 \pm 3.2 \mathrm{mV}$, respectively $( \pm \mathrm{SE} ; n=5)$. These values were more positive compared to those measured at $2 \mathrm{mM} \mathrm{Ca}^{2+}$, suggesting that it was due to increased permeability to $\mathrm{Na}^{+}$ (in conditions of external 40 or $80 \mathrm{mM} \mathrm{Na} \mathrm{Na}^{+} \mathrm{Na}^{+}$reversal potential is positive). The outwardly-directed $\mathrm{K}^{+}$efflux conductance was equally blocked by 40 and $80 \mathrm{mM} \mathrm{NaCl}$ in the presence of $0.2 \mathrm{mM} \mathrm{CaCl}_{2}$, suggesting the saturation of the blockade at $40 \mathrm{mM} \mathrm{NaCl}$ or lower level of salt (Figures 4, 5). Interestingly, the time-dependent current component was almost fully blocked, when 40 or $80 \mathrm{mM}$ $\mathrm{NaCl}$ were added on the background of $0.2 \mathrm{mM} \mathrm{CaCl}_{2}$.

\section{DISCUSSION}

Overall, data reported here demonstrate for the first time that $H$. annuus root plasma membrane has a set of ionic conductances dominated by NSCCs and KORs. Similar conductances were previously recorded in the plasma membranes of root protoplasts isolated from A. thaliana (Maathuis and Sanders, 2001; Demidchik et al., 2002, 2010; Demidchik and Tester, 2002; Shabala et al., 2006), Thellungiella halophila (Volkov et al., 2004; Volkov and Amtmann, 2006), Pisum sativum (Zepeda-Jazo et al., 2011), T. aestivum (Straltsova et al., 2015) and other species (Demidchik, 2014). To our knowledge, this work is the first patch-clamp and voltageclamp study on sunflower. It should be noted that previous works have touched on the topic of sunflower electrophysiology only in terms of measurements of membrane potential (Stankovic et al., 1997). 
In this investigation, the Helianthus $\mathrm{Na}^{+}$influx currents were also measured and analyzed (Figures 2-4). These currents showed voltage-independent activation, lack of time-dependent component and high sensitivity to $\mathrm{Gd}^{3+}$. These properties are fully in line with the characteristics of $\mathrm{Na}^{+}$-permeable NSCCs previously measured in A. thaliana (Maathuis and Sanders, 2001; Demidchik and Tester, 2002; Shabala et al., 2006) and T. halophile (Volkov et al., 2004; Volkov and Amtmann, 2006). However, sunflower $\mathrm{Na}^{+}$-permeable NSCCs showed a much weaker response to the decrease of extracellular $\mathrm{Ca}^{2+}$ as compared to Arabidopsis or Thellungiella in the range of physiological $\mathrm{Ca}^{2+}$ levels (2-0.2 mM). Thus, sunflower NSCCs has smaller $\mathrm{Na}^{+}$current density (and potentially lower number of channels per same membrane area) than Arabidopsis or Thellungiella at physiological extracellular $\left[\mathrm{Ca}^{2+}\right]$, potentially preventing toxic $\mathrm{Na}^{+}$influx and cell reactions induced by $\mathrm{NaCl}$. This makes it possible to assume that $\mathrm{Ca}^{2+}$ could cause greater inhibition of NSCCs in sunflower roots. Interestingly, the response of $\mathrm{Na}^{+}$ influx to $\mathrm{Ca}^{2+}$ correlated well with $\mathrm{Ca}^{2+}$-induced protection of root growth in sunflower seedlings treated with $\mathrm{NaCl}$ at different external $\left[\mathrm{Ca}^{2+}\right]$ (Figure 1). Growth inhibition by $80 \mathrm{mM} \mathrm{NaCl}$ was prevented by $2 \mathrm{mM} \mathrm{CaCl}$ while the treatment with 0.2 $\mathrm{CaCl}_{2}$ was not effective (Figure 1).

Results presented here also demonstrate a high sensitivity of $\mathrm{KOR}$ to $\mathrm{Na}^{+}$and suggest a relatively low sensitivity of KOR to external $\mathrm{Ca}^{2+}$ in salt-tolerant sunflower. Similar sensitivity to external $\mathrm{Na}^{+}$is known for animal KORs, such as Kv2.1 and related to $\mathrm{Na}^{+}$reaction with the high and low affinity $\mathrm{Na}^{+}$ binding sites in Kv2.1 channel (Kiss et al., 1998). Potassium outwardly-directed conductances mediated by KORs in salttolerant T. halophila decreased 1.5-1.7 times after the addition of $100 \mathrm{mM}$ external $\mathrm{Na}^{+}$(Volkov et al., 2004; Volkov and Amtmann, 2006). In salt-sensitive species $A$. thaliana, this blockade was 1.3-1.9 times both in root epidermis and leaf mesophyll cells (showing a tendency to increase with an increase in the concentration of extracellular $\mathrm{Ca}^{2+}$; Shabala et al., 2006). From the present findings, we hypothesize that enhanced sensitivity of $\mathrm{K}^{+}$efflux system to $\mathrm{Na}^{+}$can play an important role for adaptation because this will decrease $\mathrm{K}^{+}$loss under salinity conditions. It fits well within the hypothesis that maintaining a high $\mathrm{K}^{+} / \mathrm{Na}^{+}$ratio in plant cells and prevention of $\mathrm{K}^{+}$efflux under salt stress are key mechanisms of salt tolerance in higher plants (Shabala and Cuin, 2012; Demidchik et al., 2014, 2018).

Intriguingly, $\mathrm{K}^{+}$outwardly directed conductance in sunflower showed greater $\mathrm{Na}^{+}$sensitivity at higher extracellular $\mathrm{CaCl}_{2}$ levels that can have a positive effect in conditions of salinity (as cells will lose less $\mathrm{K}^{+}$; Figure 5). This can be explained by the influence of $\mathrm{CaCl}_{2}$ on the $\mathrm{Na}^{+}$-induced blockade of KORs in the case of measurements which were carried out at 20 and $2 \mathrm{mM}$ external $\mathrm{Ca}^{2+}$. In animal plasma membrane $\mathrm{K}^{+}$channels, $\mathrm{Na}^{+}$can compete with $\mathrm{K}^{+}$for binding sites within a pore region modulating channel characteristics and functions in $\mathrm{Ca}^{2+}$-dependent manner (Kiss et al., 1998; Sauer et al., 2013). In animals, $\mathrm{Ca}^{2+}$ modifies the $\mathrm{K}^{+}$channel activity via action on the surface charge, reaction with the specific binding sites at extracellular loops, effect on the EF-hands and calmodulin binding sites at cytosolic side (Shah et al., 2006). We hypothesize that the elevated extracellular $\mathrm{Ca}^{2+}$ controls the $\mathrm{Na}^{+}$block of the sunflower $\mathrm{K}^{+}$channel by increasing $\mathrm{Na}^{+}$sensitivity. Interestingly, Lemtiri-Chlieh et al. (2020) have recently reported that divalent cation $\mathrm{Mg}^{2+}$ added to the pipette solution can change both the activity of leaf NSCCs and their sensitivity to $\mathrm{Gd}^{3+}$, suggesting sophisticated interactions of cations within the NSCC complex.

Involvement of root KORs (potentially encoded by Shakertype GORK) to $\mathrm{NaCl}$ responses and salt stress adaptation have been demonstrated in a number of species (Adem et al., 2020). It is a redox-dependent phenomenon as GORK is additionally activated by ROS (Demidchik et al., 2010). Potassium loss via GORK triggered by depolarization and ROS can lead to ionic disequilibrium, induction of autophagy, and programmed cell death (Demidchik et al., 2010, 2018). Enhanced blockade of $\mathrm{KOR}$ by $\mathrm{Na}^{+}$will be the simplest and "economical" mechanism for preventing $\mathrm{K}^{+}$loss that will retain the greatest amount of metabolic energy for adaptation in salinity conditions. The cell's energy balance has recently been recognized as one of the main salt stress targets (Tyerman et al., 2019). Thus targeting KORs and their $\mathrm{Na}^{+}$sensitivity regions to save energy for reparation needs offers high hopes for generation of salt-tolerant varieties by molecular breeding techniques.

In conclusion, the data presented here strongly suggest that the moderate resistance of sunflower to $\mathrm{NaCl}$ stress is programmed at potassium and non-selective channel level via the sensitivity of ion channels to $\mathrm{Ca}^{2+}$ and $\mathrm{Na}^{+}$.

\section{DATA AVAILABILITY STATEMENT}

The raw data supporting the conclusions of this article will be made available by the authors, without undue reservation.

\section{AUTHOR CONTRIBUTIONS}

VD was responsible for research supervision, experimental design, management of experiments, data analysis, and writing the manuscript. SB and MY were involved in the preparation of plant material, research supervision, and design of experiments. $\mathrm{PH}, \mathrm{IN}, \mathrm{YT}, \mathrm{XH}$, and MK carried out electrophysiological experiments. VS and AV conducted hydroponics studies. AS and IS carried out routine cultivation of sunflower seedlings, maintained patch-clamp equipment, and participated in manuscript preparation. All authors contributed to the article and approved the submitted version.

\section{FUNDING}

This study was supported by joint Belarus-India Project 018/53 of the State Committee of Science and Technology of Belarus (to VD and SB), International Academic Exchange Research Project (China-Belarus; to VD, MY, and SH), Guangdong Province Pearl River Fellowship (to VD), and the Russian Science Foundation grant\#15-14-30008 (VD). 


\section{REFERENCES}

Adem, G. D., Chen, G., Shabala, L., Chen, Z. H., and Shabala, S. (2020). GORK channel: a master switch of plant metabolism? Trends Plant Sci. 25, 434-445. doi: 10.1016/j.tplants.2019.12.012

Assaha, D. V. M., Ueda, A., Saneoka, H., Al-Yahyai, R., and Yaish, M. W. (2017). The role of $\mathrm{Na}^{+}$and $\mathrm{K}^{+}$transporters in salt stress adaptation in glycophytes. Front. Physiol. 8:509. doi: 10.3389/fphys.2017.00509

Barbier-Brygoo, H., Vinauger, M., Colcombet, J., Ephritikhine, G., Frachisse, J., and Maurel, C. (2000). Anion channels in higher plants: functional characterization, molecular structure and physiological role. Biochim. Biophys. Acta 1465, 199-218. doi: 10.1016/s0005-2736(00)00139-5

Bressan, R. A., Hasegawa, P. M., and Pardo, J. M. (1998). Plants use calcium to resolve salt stress. Trends Plant Sci. 3, 411-412. doi: 10.1016/ S1360-1385(98)01331-4

de Angeli, A., Thomine, S., Frachisse, J. M., Ephritikhine, G., Gambale, F., and Barbier-Brygoo, H. (2007). Anion channels and transporters in plant cell membranes. FEBS Lett. 581, 2367-2374. doi: 10.1016/j.febslet.2007.04.003

Demidchik, V. (2012). "Characterisation of root plasma membrane $\mathrm{Ca}^{2+}$-permeable cation channels: techniques and basic concepts" in Plant Electrophysiology. ed. A. G. Volkov (Berlin, Heidelberg: Springer-Verlag), 339-370.

Demidchik, V. (2014). Mechanisms and physiological roles of $\mathrm{K}^{+}$efflux from root cells. J. Plant Physiol. 171, 696-707. doi: 10.1016/j.jplph.2014.01.015

Demidchik, V., Bowen, H. C., Maathuis, F. J. M., Shabala, S. N., Tester, M. A., White, P. J., et al. (2002). Arabidopsis thaliana root nonselective cation channels mediate calcium uptake and are involved in growth. Plant J. 32, 799-808. doi: 10.1046/j.1365-313x.2002.01467.x

Demidchik, V., Cuin, T. A., Svistunenko, D., Smith, S. J., Miller, A. J., and Shabala, S. (2010). Arabidopsis root $\mathrm{K}^{+}$-efflux conductance activated by hydroxyl radicals: single-channel properties, genetic basis and involvement in stress-induced cell death. J. Cell Sci. 123, 1468-1479. doi: 10.1242/ jcs. 064352

Demidchik, V., and Maathuis, F. J. M. (2007). Physiological roles of nonselective cation channels in plants: from salt stress to signalling and development. New Phytol. 175, 387-404. doi: 10.1111/j.1469-8137.2007.02128.x

Demidchik, V., and Shabala, S. (2018). Mechanisms of cytosolic calcium elevation in plants: the role of ion channels, calcium extrusion systems and NADPH oxidase-mediated 'ROS-Ca ${ }^{2+}$ Hub'. Funct. Plant Biol. 45, 9-27. doi: 10.1071/ FP16420

Demidchik, V., Shabala, S., Isayenkov, S., Cuin, T. A., and Pottosin, I. (2018). Calcium transport across plant membranes: mechanisms and functions. New Phytol. 220, 49-69. doi: 10.1111/nph.15266

Demidchik, V., Straltsova, D., Medvedev, S. S., Pozhvanov, G. A., Sokolik, A., and Yurin, V. (2014). Stress-induced electrolyte leakage: the role of $\mathrm{K}^{+}$permeable channels and involvement in programmed cell death and metabolic adjustment. J. Exp. Bot. 65, 1259-1270. doi: 10.1093/jxb/eru004

Demidchik, V., and Tester, M. A. (2002). Sodium fluxes through nonselective cation channels in the plant plasma membrane of protoplasts from Arabidopsis roots. Plant Physiol. 128, 379-387. doi: 10.1104/pp.010524

Flowers, T. J., and Colmer, T. D. (2015). Plant salt tolerance: adaptations in halophytes. Ann. Bot. 115, 327-331. doi: 10.1093/aob/mcu267

Flowers, T. J., Hajibagheri, M. A., and Clipson, N. J. W. (1986). Halophytes. Q. Rev. Biol. 61, 313-336. doi: 10.1086/415032

Flowers, T. J., Munns, R., and Colmer, T. D. (2014). Sodium chloride toxicity and the cellular basis of salt tolerance in halophytes. Ann. Bot. 115, 419-431. doi: 10.1093/aob/mcu217

Grieve, C. M., Grattan, S. R., and Mass, E. V. (2012). "Plant salt tolerance" in Agricultural salinity assessment and management. eds. W. W. Wallender and K. K. Tanji (Virginia, City of Reston: ASCE), 405-459.

Hedrich, R. (2012). Ion channels in plants. Physiol. Rev. 92, 1777-1811. doi: 10.1152/physrev.00038.2011

Isayenkov, S. V., and Maathuis, F. J. M. (2019). Plant salinity stress: many unanswered questions remain. Front. Plant Sci. 10:80. doi: 10.3389/ fpls.2019.00080

Karrenberg, S., Edelist, C., Lexer, C., and Rieseberg, L. (2006). Response to salinity in the homoploid hybrid species Helianthus paradoxus and its progenitors $H$. annuus and $H$. petiolaris. New Phytol. 170, 615-629. doi: 10.1111/j.1469-8137.2006.01687.x
Kativat, C., Poolsawat, O., and Tantasawat, P. A. (2012). Optimization of factors for efficient isolation of protoplasts in sunflower (Helianthus annuus L.). Aust. J. Crop. Sci. 6, 1004-1010.

Kiss, L., Immke, D., LoTurco, J., and Korn, S. J. (1998). The interaction of $\mathrm{Na}^{+}$and $\mathrm{K}^{+}$in voltage-gated potassium channels. Evidence for cation binding sites of different affinity. J. Gen. Physiol. 111, 195-206. doi: 10.1085/ jgp.111.2.195

Lemtiri-Chlieh, F., Arold, S. T., and Gehring, C. (2020). $\mathrm{Mg}^{2+}$ is a missing link in plant cell $\mathrm{Ca}^{2+}$ signalling and homeostasis - a study on Vicia faba guard cells. Int. J. Mol. Sci. 21:3771. doi: 10.3390/ijms21113771

Lenee, P., and Chupeau, Y. (1986). Isolation and culture of sunflower protoplasts (Helianthus annuus L.): factors influencing the viability of cell colonies derived from protoplasts. Plant Sci. 43, 69-75. doi: 10.1016/01689452(86)90110-X

Li, W., Zhang, H., Zeng, Y., Xiang, L., Lei, Z., Huang, Q., et al. (2020). A salt tolerance evaluation method for sunflower (Helianthus annuus L.) at the seed germination stage. Sci. Rep. 10:10626. doi: 10.1038/s41598020-67210-3

Maathuis, F. J. M., and Sanders, D. (2001). Sodium uptake in Arabidopsis thaliana roots is regulated by cyclic nucleotides. Plant Physiol. 127, 1617-1625. doi: $10.1104 /$ pp.010502

Makavitskaya, M., Svistunenko, D., Navaselsky, I., Hryvusevich, P., Mackievic, V., Rabadanova, C., et al. (2018). Novel roles of ascorbate in plants: induction of cytosolic $\mathrm{Ca}^{2+}$ signals and efflux from cells via anion channels. J. Exp. Bot. 69, 3477-3489. doi: 10.1093/jxb/ery056

Marschner, H. (2011). Marschner's mineral nutrition of higher plants. Cambridge USA: Academic Press. doi: 10.1016/C2009-0-63043-9

Munns, R., and Tester, M. (2008). Mechanisms of salinity tolerance. Annu. Rev. Plant Biol. 59, 651-681. doi: 10.1016/j.sajb.2019.12.014

Murashige, T., and Skoog, F. (1962). A revised medium for rapid growth and bioassays with tobacco tissue cultures. Physiol. Plant 15, 473-497.

Negrão, S., and Schmöckel, S. M. (2017). Evaluating physiological responses of plants to salinity stress. Ann. Bot. 119, 1-11. doi: 10.1093/aob/mcw191

Pilorgé, E. (2020). Sunflower in the global vegetable oil system: situation, specificities and perspectives. OCL 27:34. doi: 10.1051/ocl/2020028

Sauer, D., Zeng, W., Canty, J., Lam, Y., and Jiang, Y. (2013). Sodium and potassium competition in potassium-selective and non-selective channels. Nat. Commun. 4:2721. doi: 10.1038/ncomms3721

Shabala, S. (2013). Learning from halophytes: physiological basis and strategies to improve abiotic stress tolerance in crops. Ann. Bot. 112, 1209-1221. doi: 10.1093/aob/mct205

Shabala, S., and Cuin, T. A. (2012). Potassium transport and plant salt tolerance. Physiol. Plant. 133, 651-669. doi: 10.1111/j.1399-3054.2007.01008.x

Shabala, S., Demidchik, V., Shabala, L., Cuin, T. A., Smith, S. J., Miller, A. J., et al. (2006). Extracellular $\mathrm{Ca}^{2+}$ ameliorates $\mathrm{NaCl}$-induced $\mathrm{K}^{+}$loss from Arabidopsis root and leaf cells by controlling plasma membrane $\mathrm{K}^{+}$-permeable channels. Plant Physiol. 141, 1653-1665. doi: 10.1104/pp.106.082388

Shah, V. N., Chagot, B., and Chazin, W. J. (2006). Calcium-dependent regulation of ion channels. Calcium Bind Proteins 1, 203-212.

Sosan, A., Svistunenko, D., Straltsova, D., Tsiurkina, K., Smolich, I., Lawson, T., et al. (2016). Engineered silver nanoparticles are sensed at the plasma membrane and dramatically modify physiology of Arabidopsis thaliana plants. Plant J. 85, 245-257. doi: 10.1111/tpj.13105

Stankovic, B., Zawadzki, T., and Davies, E. (1997). Characterization of the variation potential in sunflower. Plant Physiol. 115, 1083-1088. doi: 10.1104/ pp.115.3.1083

Straltsova, D., Chykun, P., Subramaniam, S., Sosan, A., Kolbanov, D., Sokolik, A., et al. (2015). Cation channels are involved in brassinosteroid signalling in higher plants. Steroids 97, 98-106. doi: 10.1016/j.steroids.2014.10.008

Tyerman, S. D., Munns, R., Fricke, W., Arsova, B., Barkla, B. J., Bose, J., et al. (2019). Energy costs of salinity tolerance in crop plants. New Phytol. 221, 25-29. doi: 10.1111/nph.15555

Volkov, V., and Amtmann, A. (2006). Thellungiella halophila, a salt-tolerant relative of Arabidopsis thaliana, has specific root ion-channel features supporting $\mathrm{K}^{+} / \mathrm{Na}^{+}$homeostasis under salinity stress. Plant $J$. 48, 342-353. doi: $10.1111 / \mathrm{j}$. 1365-313X.2006.02876.x

Volkov, V., Wang, B., Dominy, P. J., Fricke, W., and Amtmann, A. (2004). Thellungiella halophila, a salt-tolerant relative of Arabidopsis thaliana, possesses 
effective mechanisms to discriminate between potassium and sodium. Plant Cell Environ. 27, 1-14. doi: 10.1046/j.0016-8025.2003.01116.x

White, P. J., and Broadley, M. R. (2003). Calcium in plants. Ann. Bot. 92, 487-511. doi: $10.1093 / \mathrm{aob} / \mathrm{mcg} 164$

Xue, S., Yao, X., Luo, W., Jha, D., Tester, M., Horie, T., et al. (2011). AtHKT1;1 mediates nernstian sodium channel transport properties in arabidopsis root stelar cells. PLoS One 6:e24725. doi: 10.1371/journal.pone.0024725

Zepeda-Jazo, I., Velarde-Buendía, A. M., Enríquez-Figueroa, R., Bose, J., Shabala, S., Muñiz-Murguía, J., et al. (2011). Polyamines interact with hydroxyl radicals in activating $\mathrm{Ca}^{2+}$ and $\mathrm{K}^{+}$transport across the root epidermal plasma membranes. Plant Physiol. 157, 2167-2180. doi: 10.1104/ pp.111.179671
Conflict of Interest: The authors declare that the research was conducted in the absence of any commercial or financial relationships that could be construed as a potential conflict of interest.

Copyright $\odot 2021$ Hryvusevich, Navaselsky, Talkachova, Straltsova, Keisham, Viatoshkin, Samokhina, Smolich, Sokolik, Huang, Yu, Bhatla and Demidchik. This is an openaccess article distributed under the terms of the Creative Commons Attribution License (CC BY). The use, distribution or reproduction in other forums is permitted, provided the original author(s) and the copyright owner(s) are credited and that the original publication in this journal is cited, in accordance with accepted academic practice. No use, distribution or reproduction is permitted which does not comply with these terms. 